\title{
A Study on Evaluation of the Integration of Chinese and Foreign Cultures into Oxford Junior High School English Textbooks on the Basis of Multicultural Education
}

\author{
Dan YANG $^{1} \&$ Ziqi WANG ${ }^{2}$ \\ ${ }^{1}$ Foreign Language School, Yancheng Teachers University, China \\ ${ }^{2}$ Yangzhou University, China \\ Correspondence: Dan YANG, Foreign Language School, Yancheng Teachers University, China. E-mail: \\ yangd@yctu.edu.cn
}

Received: June 10, 2021

Accepted: July 12, 2021

Online Published: July 15, 2021

doi:10.5539/ells.v11n3p33

URL: https://doi.org/10.5539/ells.v11n3p33

\begin{abstract}
This paper studies the learner evaluation results of Chinese and foreign cultural materials in Oxford Junior High School English Textbook of Yilin Edition (2nd semester of Book 8) with a questionnaire. It finds that the content of Chinese and foreign culture in this edition is rich and diverse, which can cultivate students' cross-cultural identity and communication ability. However, some typical problems exist, such as uneven distribution of Chinese and foreign cultures, lack of cultural diversity awareness, lack of interdisciplinary nature, falling to stimulate students' learning enthusiasm.
\end{abstract}

Keywords: multicultural education, Oxford junior high school English textbook, integration of Chinese and foreign cultures, textbook evaluation

\section{Introduction}

In China, English teaching is the main method for junior school students to reinforce their foreign communication ability along with the main process to help junior school students understand foreign social culture. It is also a pivotal means to helping junior school students establish correct cultural values and realize the pluralistic equality, integration and interaction of cultures of various countries.

Therefore, the first purpose of this study is to investigate the influence of the integration of Chinese and foreign cultures into Oxford Junior High School English textbooks on junior high school students' attitude towards Chinese and English culture. Besides, it aims at analyzing the influence of current English textbooks on junior school students' awareness of cultural plurality to find out whether junior high school English textbooks give full play to the role of multicultural education, and the advantages and disadvantages of Oxford Junior high school English textbooks. And finally, it is to put forward some suggestions on the further edition of junior high school English textbooks which can benefit multicultural education.

\section{Literature Review}

Looking at the relevant research and literature on the evaluation of English textbooks in the past few years, we can roughly divide these evaluation studies into two categories. The first category is to systematically evaluate a specific textbook, including internal evaluation and external evaluation. This kind of textbook evaluation is a macro evaluation, and it is also the evaluation method used in most of the textbook evaluation at present. In the second category, from the point of view of a certain teaching concept, one or more facets involved in the textbooks are selected for specific analysis. This can be regarded as the evaluation of the micro facet, but the research and literature on the evaluation of this kind of teaching materials are still rare.

\subsection{Studies Abroad}

Multicultural education is comprehensive in education reforms because it focuses on all facets of school development, including classroom structure, curriculum design and teaching practice. Multicultural education aims to ensure that these areas of education are linked to both the mission of the school and the diverse student community (Banks, 2016, pp. 118-119; 2019, pp. 68-70). At present, the research on the combination of foreign language education and multicultural education abroad mainly focuses on learners, educators and educational 
media.

Firstly, from the perspective of English language learners, Jerry L. Parker creatively combines the multicultural curriculum design principles proposed by Banks with the education of English language learners, who held that the educational reform of English learner is carried out from the facets of knowledge construction, content synthesis, prejudice reduction, fair education and school culture creation. By Embracing Equity Pedagogy to effectively serve English learners, multicultural educators provide an equal and adequate education for all (Howie \& Lisi, 2020, p. 105). Finally, by creating an empowering school culture. English learners learning therefore takes priority over "just course content" and all educational factors that contribute to junior school students' learning are considered and nurtured in order to achieve graduation with high level skills and ensure a positive future for their families (Jerry, 2019, pp. 22-35).

Secondly, from the perspective of English language educators, Maria Stec evaluated the multicultural education content in teachers' books to study its effect on the cultivation of teachers' multicultural education ability, and found that teaching materials or evaluations of teachers tended to ignore the cultural dimension. Her paper instigates our understanding of culture content provided in the instructional, standard and classical materials for teachers working in the early stages of English education (Maria, 2017, pp. 153-169).

Thirdly, from the perspective of English teaching media, Sultan S, Haris H, and Anshari A studied the functions and strategies of integrating multicultural values into textbook discourse. They concluded that through the analysis of textbook content, the textbook has rich forms of cultural expression. The function of the textbook plays a positive role in cultivating junior school students' attitude towards respecting social and cultural diversity (Sultan, Haris, \& Anshari, 2020, pp. 15-21).

\subsection{Studies at Home}

The researches in this regard in China are mainly divided into three facets:

First of all, from the perspective of education mode, China has carried out more researches on a new education model that combines college English teaching and multicultural education. By analyzing the evolution and policies of multicultural education in the United States, Professor Lin Ya proposed the requirement of adding multicultural education into the English cultural education syllabus for Chinese college junior school students (Lin, 2012, pp. 124-126).

Secondly, from the perspective of English curriculum design, Wang Hongwei, Ma Jing and Yu Yanhua took Modern College English (Intensive Reading) as the research object and respectively analyzed the principles, content and the compilation of textbooks. They found that the whole curriculum reflected the similarity of the mainstream values in China and the mainstream values in the United States, and believed that the curriculum writing guidance was insufficient to enable junior school students to form a multicultural perspective and critical thinking. They suggested bringing in foreign multicultural education experts in the compilation of textbooks and courses, and adding more supplementary materials to train junior school students' critical thinking abilities (Wang, 2012, pp. 19-21).

Finally, from the perspective of English educators, Chinese scholars attach great importance to the cultivation of multicultural literacy of English teachers themselves. Jing Li and Qunqiang Zhou put forward the professional maturing approaches for college English teachers in the context of social and cultural diversity, such as establishing the concept of multicultural education and lifelong learning. Improving multicultural teaching ability and applying multicultural education strategies (Li \& Zhou, 2018, pp. 104-105).

\section{Research Design}

\subsection{Research Subjects}

In order to study the influence of Oxford English textbooks on junior school students' cross-cultural identity and the extent to which Oxford Junior High School English meets the needs of junior school students to understand cultural diversity, we selected 100 or so junior school students from a junior high school in Yancheng, Jiangsu Province. This school belongs to the middle level of all schools and best represents the educational level of ordinary junior school students. In this study, Oxford Junior High School English Textbook of Yilin Edition (2nd semester of Book 8) is selected as the main evaluation object of the junior school students. Therefore, 100 Grade 8 junior school students from two classes were randomly selected from this junior high school as the main body of the study.

\subsection{Research Tool: Questionnaire}

This questionnaire is mainly aimed at the learner evaluation survey of the Oxford junior high school English 
textbook in the second semester of Book 8 of Yilin version, which is mainly divided into three facets:

(1) Does the content and arrangement of the current English textbooks make junior school students aware of the cultural distinctions and diversity in the world and the sense of cross-cultural identity?

(2) What is the effect of the integration of Chinese and foreign cultural materials into English textbooks on the cultivation of junior school students' awareness of cross-cultural communication?

(3) Does the content of Chinese and foreign cultures in English textbooks stimulate junior school students' attentiveness in learning and meet their needs for understanding domestic and foreign cultures?

\section{Results and Discussion}

\subsection{Results}

According to statistics, among the 122 questionnaires, 119 are valid. After the completion of each questionnaire, the original data collected will be incorporated into the SPSSAU platform for the first time, and then the original data will be processed by SPSSAU (20.0) system. The results are as follows.

Table 1. Descriptive statistics (Q1-Q9)

\begin{tabular}{|c|c|c|c|c|c|c|}
\hline & $\mathrm{N}$ & Minimum & Maximum & Mean & Std.Deviation & Median \\
\hline $\begin{array}{l}\text { Q1. I think that all cultures in the world are diverse and equal } \\
\text { and should respect, communicate and } \\
\text { blend with each other. }\end{array}$ & 119 & 1.000 & 5.000 & 1.403 & 0.693 & 1.000 \\
\hline $\begin{array}{l}\text { Q2. The English textbook I'm currently learning teaches me } \\
\text { that I should treat all cultures equally. }\end{array}$ & 119 & 1.000 & 5.000 & 1.630 & 0.852 & 1.000 \\
\hline $\begin{array}{l}\text { Q3. The English textbooks you are currently learning can } \\
\text { help me understand the similarities and distinctions between } \\
\text { domestic and foreign cultures. }\end{array}$ & 119 & 1.000 & 5.000 & 1.706 & 0.896 & 1.000 \\
\hline $\begin{array}{l}\text { Q4. At present, the content of Chinese and foreign cultures } \\
\text { meets my needs of understanding foreign cultures. }\end{array}$ & 119 & 1.000 & 5.000 & 1.840 & 0.920 & 2.000 \\
\hline $\begin{array}{l}\text { Q5. The traditional Chinese culture contained in the current } \\
\text { English textbooks can cultivate your ability to spread } \\
\text { Chinese culture in English. }\end{array}$ & 119 & 1.000 & 5.000 & 1.697 & 0.819 & 2.000 \\
\hline $\begin{array}{l}\text { Q6. The current English textbooks include the cultures of } \\
\text { many countries, not limited to countries that take English as } \\
\text { their mother tongue. }\end{array}$ & 119 & 1.000 & 5.000 & 1.782 & 0.931 & 2.000 \\
\hline $\begin{array}{l}\text { Q7. In the current English textbooks, the expressions of } \\
\text { Chinese and foreign cultures are plentiful. (for example, } \\
\text { there are illustrations, dialogue, listening, reading, writing, } \\
\text { etc.) }\end{array}$ & 119 & 1.000 & 4.000 & 1.471 & 0.662 & 1.000 \\
\hline $\begin{array}{l}\text { Q8. A wide range of fields about cultures are covered in the } \\
\text { English textbooks. (such as: human geography, literature, } \\
\text { history, customs, etiquette, politics, economy, etc.) }\end{array}$ & 119 & 1.000 & 4.000 & 1.714 & 0.804 & 2.000 \\
\hline $\begin{array}{l}\text { Q9. In the current English textbooks, the culture-related } \\
\text { English materials are easy for you to understand. }\end{array}$ & 119 & 1.000 & 4.000 & 1.723 & 0.843 & 2.000 \\
\hline
\end{tabular}

Q1-Q9 is single multiple-choice questions of degree. Each question is divided into five degrees from complete gratification to complete dissatisfaction, in which complete gratification represents the minimum value " 1 " and complete dissatisfaction represents the maximum value " 5 ". It can be seen from Table 1 that the average value of Q1-Q9 fluctuates between 1 and 2, with a median of 1 or 2, indicating that junior school students are basically in favor of the problem.

Q1-Q4 shows that junior school students have a basic sense of cultural diversity and equality, and the Yilin version of Oxford Junior High School English can cultivate this awareness and meet the basic needs of junior school students to understand foreign culture, but it can not be fully satisfied.

Q5-Q6 shows that junior school students basically agree that English textbooks can help them nurture inter-cultural communicative competence and include the cultures of many countries, but there is still room for reform.

Q7-Q9 shows that junior school students think that textbooks express culture in a wide range of forms and fields, and are relatively easy to understand. However, there may still have deficiencies in terms of the areas involved 
and the level of understanding.

Table 2. Descriptive statistics (Q10)

\begin{tabular}{lllllll}
\hline Question & $\mathrm{N}$ & Minimum & Maximum & Mean & Std.Deviation & Medium \\
\hline $\begin{array}{l}\text { Q10. Generally speaking, are you satisfied with the } \\
\text { knowledge of Chinese and foreign cultures contained in }\end{array}$ & 119 & 1.000 & 5.000 & 1.378 & 0.596 & 1.000 \\
\begin{tabular}{l} 
English textbooks? \\
\hline
\end{tabular} & & & & & & \\
\end{tabular}

It can be seen from Table 2 that the minimum value "1" of Q10 represents great gratification, while the maximum value " 5 " represents very dissatisfaction, while the mean is 1.378 , and the median is 1 , indicating that junior school students are very satisfied with the arrangement of Chinese and foreign cultural knowledge in the textbook.

Table 3. Frequency analysis (Q11-12)

\begin{tabular}{|c|c|c|c|c|}
\hline Question & Option & Frequency & $\begin{array}{l}\text { Valid Percent } \\
(\%)\end{array}$ & $\begin{array}{l}\text { Cumulative } \\
\text { percent }(\%)\end{array}$ \\
\hline Q11. In the current English & A. Chinese culture is more than foreign culture. & 53 & 44.54 & 44.54 \\
\hline textbooks, what is the & B. Foreign culture is more than Chinese culture & 17 & 14.29 & 58.82 \\
\hline distribution of Chinese culture & C. There are many cultures both at home and abroad & 46 & 38.66 & 97.48 \\
\hline and foreign culture? & D. There is not much Chinese culture and foreign culture & 3 & 2.52 & 100.00 \\
\hline $\begin{array}{l}\text { Q12. How do you want to } \\
\text { distribute the proportion of }\end{array}$ & $\begin{array}{l}\text { A. Chinese culture is larger than foreign culture, so we can learn to } \\
\text { express and spread our own culture in English. }\end{array}$ & 52 & 43.70 & 43.70 \\
\hline $\begin{array}{l}\text { Chinese and foreign cultural } \\
\text { materials in the English }\end{array}$ & $\begin{array}{l}\text { B. Foreign culture is larger than Chinese culture, which allows us to } \\
\text { know more about and identify with other countries' cultures. }\end{array}$ & & 6.72 & 50.42 \\
\hline materials you have learned? & $\begin{array}{l}\text { C. The proportion of Chinese and foreign cultures should be evenly } \\
\text { distributed, so that we can not only understand the cultures of other } \\
\text { countries, but also convey our own cultures. }\end{array}$ & 59 & 49.58 & 100.00 \\
\hline
\end{tabular}

As can be seen from the above table: the proportion distribution of Q11 shows that most of the samples are "Chinese culture is more than foreign culture", accounting for $44.54 \%$. However, the proportion of more samples of foreign culture is only $14.29 \%$. It shows that the proportion of Chinese culture in the English textbook is larger than that of foreign culture.

From the perspective of the proportion distribution of Q12, most of the samples are that "the proportion of Chinese and foreign cultures should be evenly distributed, which not only allows us to understand other cultures but also allows us to convey our own culture" accounts for the largest proportion, at $49.58 \%$, while only 8 people think that foreign culture should be more than Chinese culture.

Table 4. Multiple-choice analysis (Q13)

\begin{tabular}{llll}
\hline Q13 & \multicolumn{2}{l}{ Responsivity } & Penetration \\
\cline { 2 - 4 } & $\mathrm{n}$ & Response rate & $(\mathrm{n}=119)$ \\
\hline A literature & 69 & $19.66 \%$ & $57.98 \%$ \\
B policy and economy & 46 & $13.11 \%$ & $38.66 \%$ \\
C scenic spot & 82 & $23.36 \%$ & $68.91 \%$ \\
D history and traditional culture & 93 & $26.50 \%$ & $78.15 \%$ \\
E the culture about life & 61 & $17.38 \%$ & $51.26 \%$ \\
Conclusion & 351 & $100 \%$ & $294.96 \%$ \\
Goodness-of-fit test $: \chi^{2}=18.957 \mathrm{p}=0.001$ & & & \\
\hline
\end{tabular}

Q13 mainly investigates the cultural areas that junior school students want to be involved in English textbooks. From Table 4, the goodness-of-fit test of Q13 shows chi $=18.957, \mathrm{p}=0.001<0.05$, which means that the selection proportion of each item is significantly non-identical. To be precise, the response rate and penetration of C scenic spots, D history and traditional culture are $23.36 \% 68.91 \%$ and $26.50 \% 78.15 \%$, which are obviously higher, while political economy is the lowest $(13.11 \%$ and $38.66 \%)$. 
Table 5. Multiple-choice analysis (Q14)

\begin{tabular}{llll}
\hline Q14 & \multicolumn{2}{l}{ Responsivity } & Penetration $(\mathrm{n}=119)$ \\
\cline { 2 - 3 } & $\mathrm{n}$ & Response rate & \\
\hline A. articles & 74 & $23.95 \%$ & $62.18 \%$ \\
B. dialogues & 78 & $25.24 \%$ & $65.55 \%$ \\
C. video & 85 & $27.51 \%$ & $71.43 \%$ \\
D. radio & 44 & $14.24 \%$ & $36.97 \%$ \\
E. chart & 28 & $9.06 \%$ & $23.53 \%$ \\
Conclusion & 309 & $100 \%$ & $259.66 \%$ \\
\hline
\end{tabular}

Note. Goodness-of-fit test: $\chi^{2}=38.977 \mathrm{p}=0.000$.

The main purpose of Q14 is to investigate what forms of culture junior school students hope the textbook introduce. From Table 5, the goodness-of-fit test of Q13 shows chi $=38.977, \mathrm{p}=0.000<0.05$. And An article, B dialogue and $\mathrm{C}$ video materials are the main selection objects.

Table 6. Multiple-choice analysis (Q15)

\begin{tabular}{|c|c|c|c|}
\hline \multirow[t]{2}{*}{$\bar{Q} 15$} & \multicolumn{2}{|c|}{ Responsivity } & \multirow[t]{2}{*}{ Penetration $(\mathrm{n}=119)$} \\
\hline & $\mathrm{n}$ & Response rate & \\
\hline A. Chinese traditional mainstream culture & 100 & $34.60 \%$ & $84.03 \%$ \\
\hline B. the culture of native English-speaking countries & 71 & $24.57 \%$ & $59.66 \%$ \\
\hline $\begin{array}{l}\text { C. cultures of other languages (Japan and South Korea, Russia, } \\
\text { France and Germany, etc.) }\end{array}$ & 66 & $22.84 \%$ & $55.46 \%$ \\
\hline D. Chinese minority culture & 52 & $17.99 \%$ & $43.70 \%$ \\
\hline Conclusion & 289 & $100 \%$ & $242.86 \%$ \\
\hline
\end{tabular}

Note. Goodness-of-fit test: $\chi^{2}=16.896 \mathrm{p}=0.001$.

The main purpose of Q15 is to investigate the cultural content that junior school students want to be included in English textbooks. In Table 6, the goodness-of-fit test of Q15 shows chi $=16.896, p=0.001<0.05$. To be more exact, the response rate and penetration of A Chinese traditional mainstream culture is the highest $(34.60 \%$ and $84.03 \%$ ), while D minority culture is the lowest $(17.99 \%$ and $43.70 \%)$.

Table 7. Frequency analysis (Q11-12)

\begin{tabular}{|c|c|c|c|c|}
\hline Question & Option & Frequency & Valid Percent (\%) & Cumulative percent $(\%)$ \\
\hline Q16. In the current English materials learned, the content about & $\mathrm{Y}$ & 112 & 94.12 & 94.12 \\
\hline $\begin{array}{l}\text { Chinese and foreign cultures are closely related to the reality of } \\
\text { life (such as diet, festivals, etc.). }\end{array}$ & $\mathrm{N}$ & 7 & 5.88 & 100.00 \\
\hline Q17. In the current English materials, most of the content related & $\mathrm{Y}$ & 107 & 89.92 & 89.92 \\
\hline $\begin{array}{l}\text { to culture is related to the content of other subjects. (For example, } \\
\text { when explaining the name of each country, it will point out the } \\
\text { geographical location of the country on the earth. }\end{array}$ & $\mathrm{N}$ & 12 & 10.08 & 100.00 \\
\hline Q18. In the current English textbooks, we should add materials & $\mathrm{Y}$ & 117 & 98.32 & 98.32 \\
\hline that compare Chinese and foreign cultures. & $\mathrm{N}$ & 2 & 1.68 & 100.00 \\
\hline Q19. You think that the English textbooks you have learned can & $\mathrm{Y}$ & 113 & 94.96 & 94.96 \\
\hline $\begin{array}{l}\text { make you more interested in Chinese and foreign cultures and } \\
\text { hope to learn more about them. }\end{array}$ & $\mathrm{N}$ & 6 & 5.04 & 100.00 \\
\hline
\end{tabular}

Q16-Q19 are judgment questions, in which Q16, Q17 and Q19 are aimed at evaluation of textbooks.

It can be seen from Q16 in the above table that in the current English materials, junior school students basically think that the content related to Chinese and foreign cultures is closely related to the reality of life (such as diet, festivals, etc.), because the proportion of "yes" is $94.12 \%$.

In Q17, more than $80 \%$ of the junior school students agree that the culture-related content in the textbook is mostly related to the content of other subjects, (for example, the geographical location of each country on the earth will be pointed out when explaining the name of each country).

And junior school students generally think that the textbook can stimulate junior school students' attentiveness in 
Chinese and foreign cultures, owing to $94.96 \%$ of the answers in Q19 are "yes".

Q18 is a textbook recommendation-junior school students generally think that more Chinese and foreign cultural contrast materials should be added to the textbook, for $8.32 \%$ of the samples are "yes".

\subsection{Discussion}

According to the results of the questionnaire, the authoress makes an analysis from the following four facets.

\subsubsection{Arrangement of Content, Presentation Form and Cultural Fields}

The survey results of the above Q6.8.11.16.17 show that the multicultural education of the textbook itself is mainly achieved through the addition of Chinese and foreign cultures. From the perspective of content, the English textbook involves cultures of many countries, not limited to China and English-speaking countries, but the proportion of Chinese culture is a little bit higher than foreign cultures. In terms of its form, it adopts a variety of forms to introduce divergent cultures, including articles, audio-visual materials, compositions and forms, but there is a slight deficiency in connection with other disciplines. It is also rich and diverse in the cultural fields involved, such as literature, customs, behavior etiquette and so on, which are related to real life, and stimulate junior school students' attentiveness in culture learning.

\subsubsection{Functional Level of the Textbook}

The average values of Q1, Q2, Q3 and Q5 show that junior school students basically agree with cultural distinctions, diversity and equality, and English textbooks play a key role in cultivating their awareness of cultural diversity, and at the same time cultivate junior school students' ability of cross-cultural communication, making them better equipped to use English to spread their own culture. Thus, it can be seen that the compilation of English textbooks pays attention to the integration of the concept of multicultural education and has indeed played a positive role in multicultural education.

\subsubsection{Students' Satisfaction Level}

Q4.7.10.19 shows that junior school students are basically satisfied with their current English textbooks, and English textbooks basically meet the basic needs of junior school students to understand foreign culture, and can also stimulate junior school students' attentiveness in Chinese and foreign cultures.

However, the teaching materials can not fully meet the needs of junior school students to understand Chinese and foreign cultures, especially in the diversity of cultural content and fields. Secondly, the degree of difficulty of cultural content has not completely reached the degree that it is easy for junior school students to understand.

Finally, the proportion of Chinese culture is larger than that of foreign cultures, and junior school students prefer an equal distribution of Chinese and foreign cultures.

\section{Problems and Suggestions}

The materials that reflect the sense of multiculturalism in this set of textbooks have some problems, which are recommended as follows:

First of all, the content about culture is old and simple. Because the textbook is not updated in time, it is out of date and does not meet the needs of junior school students, and far away from the cognitive field of today's junior school students. And most of the content is relatively simple, scrappy, and do not really highlight the cultural characteristics of a foreign country, showing its dissimilarities from China.

Secondly, the selected cultural content is mainly Chinese traditional culture and English-speaking countries' culture, while the content of domestic minority cultures and foreign non-English-speaking countries' cultures are very few.

Thirdly, the connection between cultural content and other subjects is insufficient, and the selected content of the textbook only serves English teaching, ignoring the leaping teaching function to a certain extent.

Finally, the form of expression of the content is not sufficiently conducive to the junior school students' understanding and attentiveness. Although the content is full of pictures and cartoons, many of them are still based on articles and tables, which is not easy to stimulate junior school students' subjective ability and attentiveness in learning.

On this basis, the author puts forward some suggestions on textbook adaptation: updating cultural content, strengthening links with other disciplines and following the regulations of students' physical and mental development. 


\section{Acknowledgements}

Funding: The paper was funded by "Projects of Jiangsu Higher Education Reforms" (Grant Number: 2019JSJG323).

\section{References}

Banks, J. A. (2019). An Introduction to Multicultural Education (6th ed.). Seattle, WA: Pearson.

Banks, J. A., \& Banks, C. (Eds.). (2016). Multicultural Education: Issues and Perspectives. Boston, MA: Wiley.

Howe, W., \& Lisi, P. L. (2018). Becoming a Multicultural Educator: Developing Awareness, Gaining Skills, and Taking Action (3rd ed.). Los Angeles, CA: Sage.

Li, J., \& Zhou, Q. Q. (2018). English Teachers' Professional Development from the Perspactive of Multi-cultural Education. English Plaza: Academic Research, 9, 104-105.

Lin, Y. (2012). Implications of American Multi-cultural Education for China's College English Cultural Education. The Frontier, 20, 124-126.

Parker, J. L. (2019). Multicultural education as a framework for educating English language learners in the United States. International Journal of Multidisciplinary Perspectives in Higher Education, 4(1), 22-35. https://doi.org/10.32674/jimphe.v4i1.1404

Sultan, S., Haris, H., \& Anshari, A. (2020). Functions and strategies to the integration of multicultural values in textbook discourse for elementary school students. Lingua Cultura, 14(1), 15-21. https://doi.org/10.21512/lc.v14i1.6219

Wang, H. W., Ma, J., \& Yu, Y. H. (2012). Curriculum Analysis and Strategies from the Perspective of Multi-cultural Education. Heilongjiang Education: Research and Assessment of Higher Education, 3, $39-41$.

\section{Copyrights}

Copyright for this article is retained by the author, with first publication rights granted to the journal.

This is an open-access article distributed under the terms and conditions of the Creative Commons Attribution license (http://creativecommons.org/licenses/by/4.0/). 